\title{
Invasion of fall armyworm (Spodoptera frugiperda) in India: nature, distribution, management and potential impact
}

\author{
S. B. Suby ${ }^{1, \dagger}$, P. Lakshmi Soujanya ${ }^{1, \dagger}$, Pranjal Yadava ${ }^{1}$, Jagadeesh Patil ${ }^{2}$, \\ K. Subaharan ${ }^{2}$, G. Shyam Prasad ${ }^{3}$, K. Srinivasa Babu ${ }^{\text {}}$, S. L. Jat ${ }^{1}$, K. R. Yathish ${ }^{1}$, \\ Jyothilakshmi Vadassery $^{4}$, Vinay K. Kalia ${ }^{5}$, N. Bakthavatsalam ${ }^{2}$, J. C. Shekhar ${ }^{1}$ \\ and Sujay Rakshit ${ }^{1}$ *
}

\author{
${ }^{1}$ ICAR-Indian Institute of Maize Research, Punjab Agricultural University Campus, Ludhiana 141 004, India \\ ${ }^{2}$ ICAR-National Bureau of Agricultural Insect Resources, Bengaluru 560 024, India \\ ${ }^{3}$ ICAR-Indian Institute of Millets Research, Hyderabad 500 030, India \\ ${ }^{4}$ DBT-National Institute of Plant Genome Research, New Delhi 110 067, India \\ ${ }^{5}$ ICAR-Indian Agricultural Research Institute, New Delhi 110 012, India
}

Fall armyworm (FAW; Spodoptera frugiperda (J. E. Smith)) is emerging as the most destructive pest of maize in India since its report in May 2018. Its rapid spread to more than $90 \%$ of maize-growing areas of diverse agro-ecologies of India within a span of 16 months presents a major challenge to smallholder maize farmers, maize-based industry, as well as food and nutritional security. FAW has been reported from other crops as well like sorghum and millets with varied proportion of economic damage. In this review, the transboundary movement of FAW, role of ecology, its spread and damage are discussed. Management of FAW by developing and deploying various pest management tools is elaborated. The role of agroecological measures for reducing FAW damage with African experiences has also been highlighted.

Keywords: Agro-ecology, fall armyworm, host plant resistance, integrated pest management, transgenics.

MAIZE (Zea mays L.) is the most important cereal crop being cultivated in an area of $180.63 \mathrm{~m}$ ha in 165 countries across the world with a production of 1134 million tonnes growing at an average annual rate of $3.46 \%$ (ref. 1). It is widely valued for its extensive use as feed, fodder and as raw material for a large number of industrial applications ${ }^{2}$. In India, maize is the third most important cereal after rice and wheat, both in terms of area and production, registering maximum growth rate among food crops $^{3}$. Though maize is emerging as an important industrial crop in India, its productivity (3.1 tonne/ha) is much lower than the world average (5.62 tonne/ha) ${ }^{3}$. Besides socio-economic factors like low adoption of hybrids and lack of policy support to the maize farmers, biotic and abiotic stresses are significant bottlenecks in attaining

${ }^{\dagger}$ Equally contributed.

*For correspondence. (e-mail: s.rakshit@icar.gov.in) fullest potential of the yield gains in maize. In India till recently three insect pests, viz. spotted stem borer (Chilo partellus Swinhoe), pink stem borer (Sesamia inferens Walker) and shoot fly (Atherigona spp.) were of major consequences. Since the report of the invasive pest fall armyworm (FAW; Spodoptera frugiperda J. E. Smith) in maize in May 2018, it has spread rapidly to all maizegrowing ecologies of India, except Himachal Pradesh, and Jammu and Kashmir within a span of 16 months, casting a shadow on maize production in the country. In this article, we discuss the ecology and behaviour, extent of the spread of this insect in India and beyond in the sub-continent, strategies to manage its potential impact on maize production.

\section{Transboundary movement of fall armyworm}

Fall armyworm (FAW) is native to tropical and subtropical Americas and is known as a sporadic pest in the United States since 1797. A severe outbreak of FAW on corn and millets was documented in 1912 (ref. 4). In Latin America, FAW was observed to cause up to $73 \%$ yield loss in maize ${ }^{5}$. Outside Americas FAW first invaded Africa, as reported from Sao Tome, Nigeria, Benin and Togo in 2016 (ref. 6). In India, its presence was confirmed in May 2018 by the University of Agricultural and Horticultural Sciences, Shivamogga, Karnataka ${ }^{7}$. Since then, it has spread within the country and moved eastwards to countries bordering India, viz. Bangladesh (December 2018), Myanmar (December 2018), Sri Lanka (January 2019), China (January 2019) and Nepal, and to Thailand (December 2018), South Korea and Japan (July 2019). Temporal spread of FAW within India has been documented ${ }^{8}$ since its report from Karnataka in May 2018. FAW spread from peninsular India to the North and North East during 2018 and early 2019 respectively. With the 


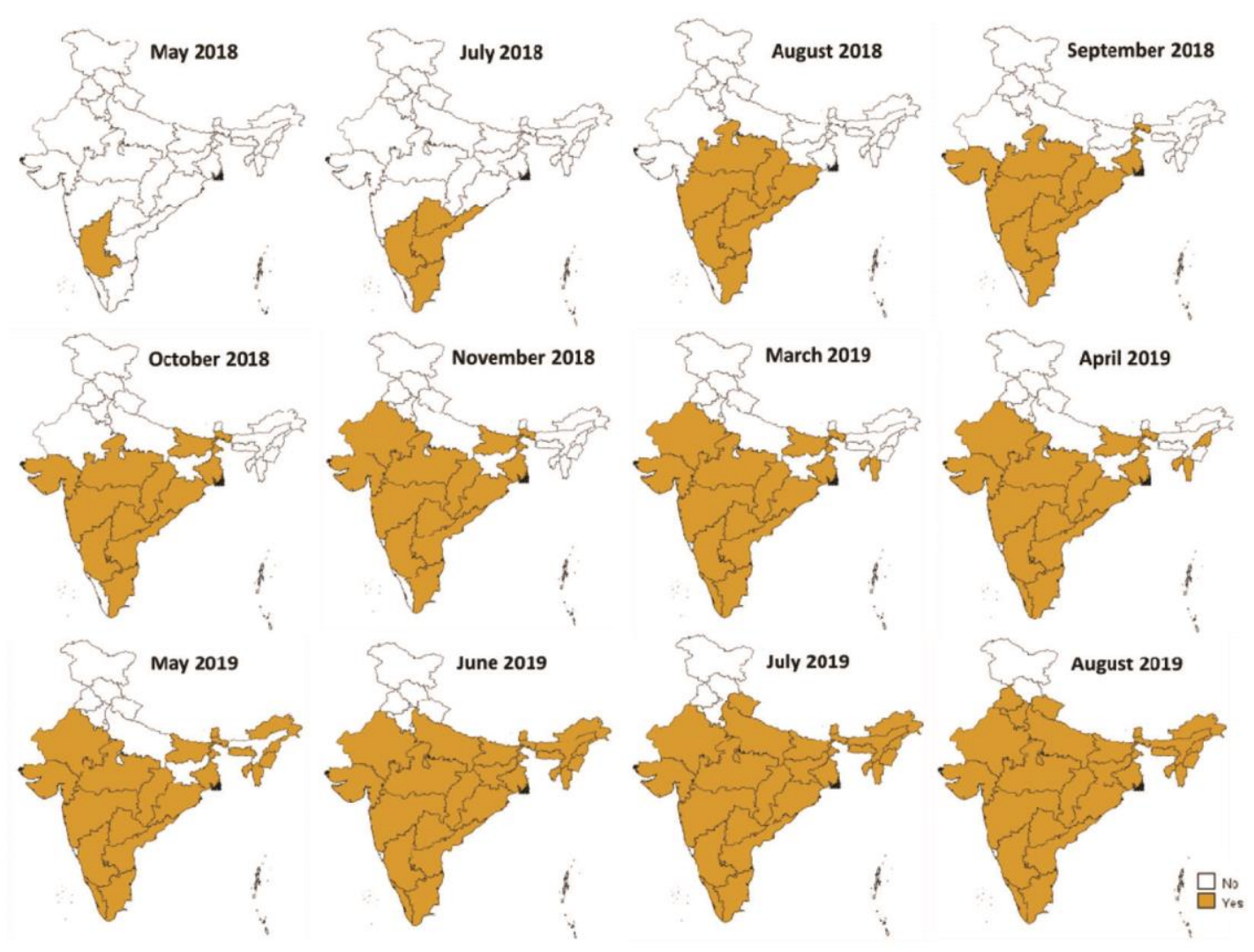

Figure 1. Temporal spread of fall armyworm (FAW) in India from May 2018 to August 2019, colouration of the states indicates reporting of FAW and does not indicate the intensity of damage (reproduced from Rakshit et al.)

progression of the 2019 monsoon, FAW incidence has been reported from the northern and northwestern parts of the country as well (Figure 1).

\section{Host preference and economic damage}

FAW is a polyphagous pest reported to attack 353 plant species belonging to 76 plant families ${ }^{9}$. However, it is primarily a pest of grasses, preferring maize the most. Besides, it can also cause economic damage to other cereals and millets. FAW attacks maize from seedling emergence to ear development stage. The female lays over a thousand eggs in single or multiple clusters. Upon hatching, the early instar secretes silken thread and is dispersed through wind (Figure $2 a$ ). The first and second instar larvae found on the upper surface of the leaves scrape the epidermis resulting in elongated papery windows all over the leaves (Figure $2 a$ and $b$ ). Third instar onwards, the larvae settle in the whorl and their feeding renders a series of holes and faecal matter in the unfurling leaves. Their feeding rate increases with growth; thus, the size of holes and amount of faecal matter also increase (Figure $2 c$ ). The sixth instar larvae defoliate heavily and leave a large amount of faecal matter in the plant whorl. Older larvae sometimes bore the developing internodes of early whorl stage of maize and cause plant death (Figure $2 d$ ). The larvae may attack tassel (Figure $2 e$ ) and developing ears (Figure $2 f$ ) as well. First to third instar larvae of FAW are quiet small and eat $2 \%$ of the total foliage consumed in their life cycle, while it is $4.7 \%, 16.3 \%$ and $77.2 \%$ for the fourth, fifth and sixth instars which heavily defoliate the crop ${ }^{10}$. Besides maize, FAW incidence was closely monitored in sorghum and other millet fields during both kharif 2018 and rabi 201819. Based on the whorl damage, sorghum was found to be the most preferred host among millets $(60.1 \%)$, followed by pearl millet $(41.4 \%)$, barnyard millet $(22.9 \%)$ and finger millet $(10.2 \%)^{11}$.

FAW consists of two strains, viz. corn strain ' $\mathrm{C}$ ' which feeds predominantly on maize, sorghum and cotton, and rice strain ' $R$ ' which prefers rice and turf grass ${ }^{12}$. Molecular genetic diversity studies suggest that the FAW population in India belongs to the ' $R$ ' strain based on polymorphisms in the Cytochrome oxidase subunit I gene $(C O I)^{13}$. Later, using other markers the Indian FAW population was found to be predominantly ' $\mathrm{C}$ ' type by $T p i$ and ' $\mathrm{R}$ ' type by $C O I$, which strongly indicates inter-strain hybrids of FAW in Africa and India, arising from a common small founder population ${ }^{14}$. The FAW genome, as sequenced from Sf21 cell line, is $358 \mathrm{Mb}$ in size with 11,595 genes and shares significant homology with that 


\section{REVIEW ARTICLES}
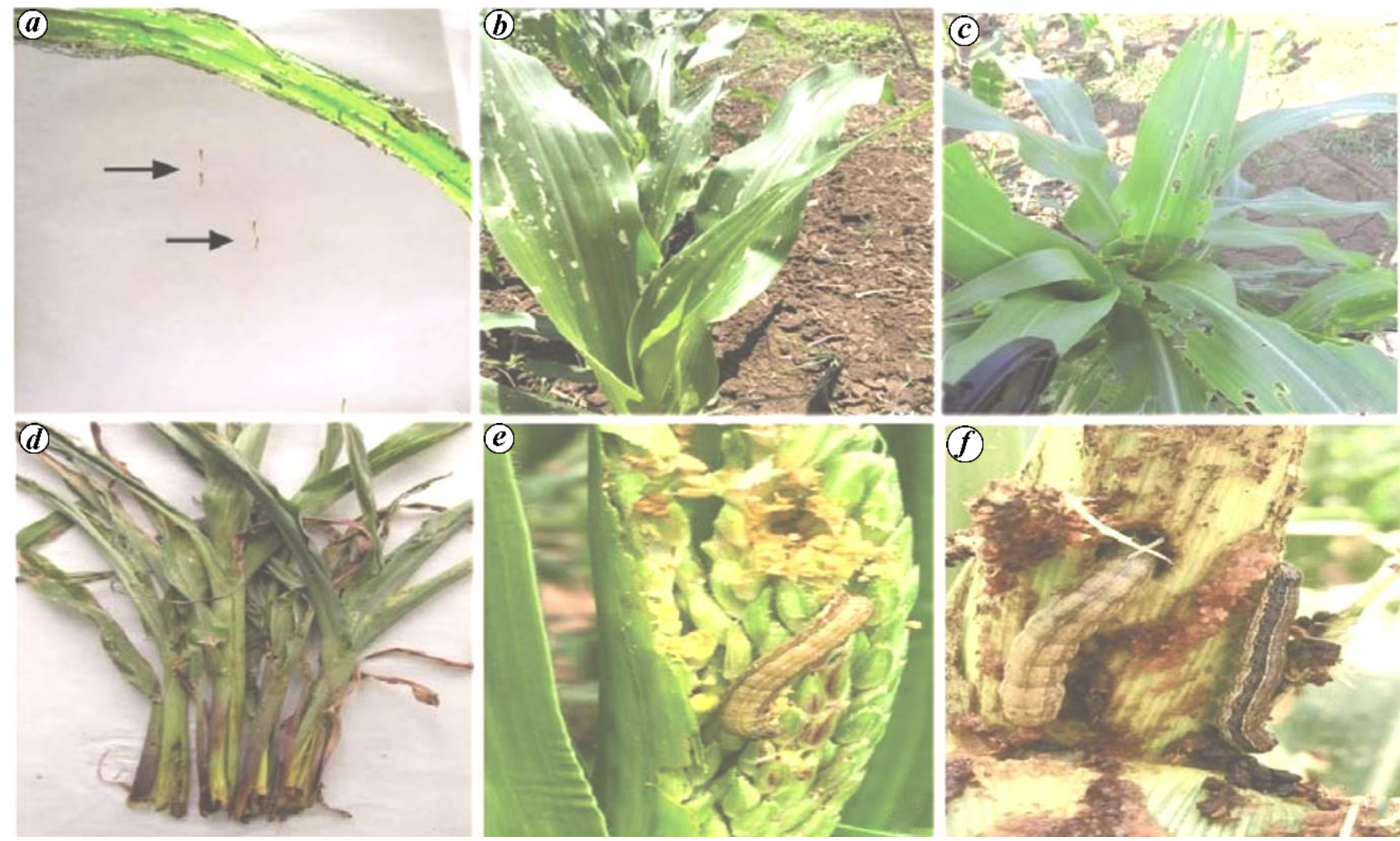

Figure 2. (a) Dispersal of FAW 1st instar larvae through ballooning (arrow marks), $(\boldsymbol{b}, \boldsymbol{c})$ damage of maize foliage, (d) dead maize plants by FAW boring into the developing stalk, $(\boldsymbol{e})$ tassel damage and $(\boldsymbol{f})$ cob damage.

of the silkworm genome ${ }^{15}$. However, FAW genome from Sf9 cell line reported $451 \mathrm{Mb}$ genome size. The genomes of both $\mathrm{C}$ and $\mathrm{R}$ strains as sequenced are 438 and $371 \mathrm{Mb}$ respectively ${ }^{16}$. The $\mathrm{C}$ strain contains 21,700 protein coding genes, whereas the $\mathrm{R}$ strain is predicted to have 26,329 genes. Significant expansions of genes associated with chemosensation and detoxification were found in FAW. These expansions are largely attributable to tandem duplications, a possible adaptation mechanism enabling polyphagy. Recently, two chromosome-level FAW genomes were reported using one male and one female adult moth collected from the Yunnan Province, China $^{17}$. The genome size was found to be $542.42 \mathrm{Mb}$ for male and $530.77 \mathrm{Mb}$ for female with 22,201 predicted genes in the male genome. A notable expansion of cytochrome $\mathrm{P} 450$ and glutathione $S$-transferase gene families often associated with pesticide detoxification and tolerance was found.

\section{Strategies adopted for management}

\section{Host plant resistance}

Host plant resistance (HPR) to herbivorous insects is widely involved in crop protection against insect pests. A number of maize germplasm sources of temperate and tropical background have been reported as sources of resistance to FAW due to low foliar damage (Supplementary Table 1). First reported FAW resistant lines were selected from Antigua $2 \mathrm{D} \times(\mathrm{B} 10 \times \mathrm{B} 14)$ and Texas Experimental Hybrid 6417 (ref. 18). Classical plant breeding efforts over the years by researchers from USDA-ARS on germplasm of Caribbean origin, particularly Antigua, yielded a number of temperate maize inbred lines combining resistance to FAW and southwestern corn borer. Resistant lines developed are presented in the Supplementary Table 1 (refs 19-32). Since the onset of FAW attack in India, a large set of diverse maize germplasms are being screened for FAW resistance at the Winter Nursery Centre of ICAR-IIMR, Hyderabad under natural infestation, assured with early planting of susceptible lines all around the field. In this process, seven promising maize lines, viz. DMR E63/CML 287-4-14-2B,

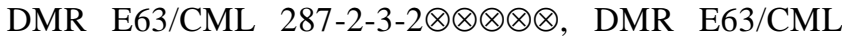
287-3-3- $\otimes \otimes \otimes \otimes \otimes$, DMR E63/CML 287-4-14-3B, DMR E63/CML 287-4-89-4B, DMR E63/CML 287-5-4-1B and P31C4S5B-85-\#\#-1-4-5-B*5-1-B-1 have been identified as resistant to FAW, which needs further confirmation.

Resistant sources against FAW have been reported in sorghum at various crop growth stages ${ }^{33,34}$. Sorghum accession, plant introduction (PI) 147573 was resistant to 
FAW over MP 708 (resistant check), but at 14 days after infestation all the 9 sorghum accessions were as resistant as MP 708 with significantly less damage than AB24E (susceptible check). This suggests that sorghum possesses induced resistance in the whor ${ }^{35}$. FAW resistance in pearl millet was also reported in Tifton no. 153 and Tifton no. 240, and antibiosis was attributed to be the resistance mechanism ${ }^{36}$.

\section{Mechanisms of host plant resistance}

Plants combat herbivorous insects by means of physiological, morphological and biochemical defence mechanisms. Mophological features attributed to FAW resistance include leaf toughness ${ }^{37}$, trichome density ${ }^{38}$ and thicker cell wall complex of epidermal layer ${ }^{39}$ which acts as a barrier to prevent insect feeding. The biochemical traits, viz. abundance of crude and acid detergent fibre ${ }^{40}$ were reported to confer FAW resistance in maize. Higher concentration of amino acids, viz. aspartic acid and tyrosine ${ }^{41}$ confers FAW resistance in maize, whereas higher concentrations of total nitrogen was highly correlated with FAW resistance in sorghum ${ }^{34}$. Higher amounts of leaf cuticular lipids $^{41}$, polyphenol compounds maysin and chlorogenic acid $^{42}$ and benzoxazinoids (BXs) play a crucial role in maize defence against insect herbivores ${ }^{43}$. The FAW resistant Antiguan inbred MP 708 contains elevated defensive proteins ${ }^{44}$; higher levels of $\mathrm{JA}^{45}$ and $(\mathrm{E})-\beta$ caryophyllene-JA responsive indirect defence volatile ${ }^{46}$.

The myriad mechanisms of FAW resistance reported above in diverse maize germplasms suggest the quantitative nature of resistance. The key genomic regions were identified on chromosomes 1, 5, 7 and 9 in MP 704 and MP 708 (refs 47, 48; these have combined resistance to both FAW and southwestern corn borer). Subsequently, using composite interval mapping (CIM) and multiple interval mapping (MIM), 24 QTLs explaining up to $26.5 \%$ of the total phenotypic variation, and 36 QTLs and 10 interactions for FAW leaf-feeding damage in MP 704 were identified $^{49}$. However, no resistance gene ( $\mathrm{R}$ gene) has been identified to confer tolerance against chewing herbivores in maize or any other crop plant so far.

\section{Transgenics}

The advent of transgenic maize expressing $B t$ proteins was a significant progress in insect-pest management. In maize, a total of 179 events have been commercially approved for cultivation with lepidopteran insect resistance trait across 13 countries. All these events harbour one or more combinations of 13 different cry genes (Supplementary Table 2). Out of the 13 cry genes, 7 have been specifically identified for conferring FAW resistance. These are vip3Aa20, crylF, crylFa2, crylA.105, cry $2 A b 2$, crylAb and mocrylF. The plant-expressed $B t$ proteins confer resistance to lepidopteran insects by selectively damaging their midgut lining. $B t$ maize, especially with $C r y l F$ was found to reduce more than $50 \%$ of the FAW population ${ }^{50}$. In the last few years, fieldevolved resistance to $C r y l F$ and $C r y l A b$ expressing maize has been reported in some FAW populations from Puerto Rico, Florida and North Carolina ${ }^{51,52}$, Brazil $^{53}$ and Argentina $^{54}$. Field observations showed that CrylAb maize provided partial control of Spodoptera frugiperda in field trials conducted with drought-tolerant $B t$ maize varieties in East Africa ${ }^{55}$. The emerging scenario of breakdown of resistance of $B t$ transgenics against some populations of FAW points to the need of greater attention to insect resistance management strategies at the field level.

\section{Management of fall armyworm}

Since the occurrence of FAW, chemical insecticides have been widely used for its management in maize. The efficacy of selected synthetic insecticides was tested against FAW in maize ${ }^{56}$. Control of FAW in early instar is more effective than attempting controlling at late stages when they are stronger to resist control measures and the damage caused is also more significant. Therefore, monitoring activities together with need-based application of insecticides is necessary for sustainable management of FAW. Currently, in India, the Central Insecticide Board and Registration Committee (CIB and RC) has recommended the insecticides, namely chlorantraniliprole 18.5 SC @ $0.4 \mathrm{ml} / 1$, spinetoram $11.7 \% \mathrm{SC} @ 0.5 \mathrm{ml} / 1$, thiamethoxam 12.6\% + lambda cyhalothrin 9.5\% ZC @ $0.25 \mathrm{ml} / 1$ for minimizing the damage in maize. The Government of India (GoI) has recently recommended the use of cyantraniliprole 19.8\% + thiamethoxam 19.8\% FS@ $6 \mathrm{ml} / \mathrm{kg}$ seed as seed treatment against FAW.

\section{Biorational pesticides}

Integrated use of various non-chemical management options significantly reduces dependence on chemical pesticides for the management of insect pests. Various options available to manage FAW are discussed below.

Entomopathogenic microbes, nematodes and viruses: Entomopathogens such as fungi, bacteria, nematodes and viruses have shown potential for the control of FAW ${ }^{57-62}$ (Supplementary Table 3). Among the naturally occurring insect viruses, multiple nucleopolyhedrovirus (SfMNPV) has potential for use in the management of $\mathrm{FAW}^{63}$. Natural epizootics of Metarrhizium rileyi (Figure 3) were reported to cause significant larval mortality ranging from $1.87 \%$ to $18.30 \%$ in Karnataka ${ }^{64}$. It was observed that entomofungal pathogen Nomuraea rileyii caused 10 $15 \%$ larval infection ${ }^{65,66}$. 


\section{Parasitoids and predators}

Surveys have documented large numbers of parasitoids and predator species emerging from FAW larvae from various studies ${ }^{65-71}$. Larval parasitoids Coccygidium melleum, Eriborus sp., Exorista sorbillans and predators Harmonia octomaculata, Coccinella transversalis were reported ${ }^{65}$. Other parasitoid species that emerged from FAW were egg parasitoids Telenomus sp., Trichogramma sp., gregarious larval parasitoid Glyptapanteles creatono$t i$ and solitary larval parasitoid Campoletis chloridae ${ }^{66}$; other than these predators Forficula was also reported ${ }^{66}$ Solitary endo-parasitoids Cotesia marginiventris (Cresson) and Chelonus insularis Cresson. were reported from FAW larvae ${ }^{69,70}$ (Supplementary Table 4). Egg larval parasitoid Chelonus sp. was found predominant, which has a potential for biological control of FAW ${ }^{71}$. Other common FAW predators observed in maize are pentatomid bugs, spiders, predatory wasps, ladybird beetles, mirid bugs, earwigs and rove beetles ${ }^{71}$.

\section{Botanicals}

Plant-derived pesticides are attractive alternatives to synthetic insecticides and constitute an affordable tool for insect pest management. Several plant species have shown insecticidal properties against $\mathrm{FAW}^{72-74}$ (Supplementary Table 5). Extracts of neem, Azadirachta indica, boldo Peumus boldus Molina ${ }^{75}$, Schinnus molle, Phytolacca dodecandra $^{56}$, Argemone ochroleuca Sweet (Papaveraceae) ${ }^{76}$, garlic + neem $^{77}$ showed efficacy against FAW larvae. At present, potent botanicals against FAW have to be identified. Multi-location field studies and compatibility of botanical pesticides with other pest management options should be conducted to assess their efficacy.

\section{Semiochemicals}

The pheromone composition of FAW females has been identified as a major and two minor components. (Z)-9-

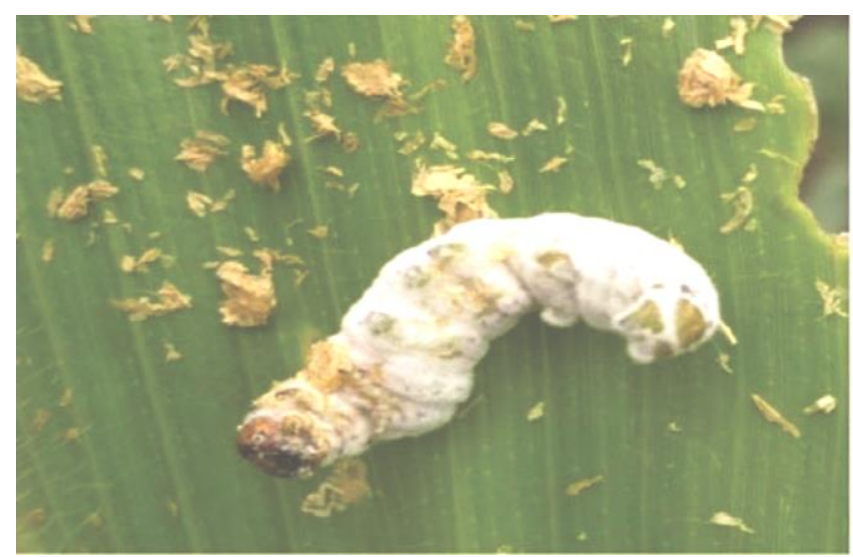

Figure 3. Nomuraea rileyi infected FAW larva. tetradecenyl acetate (Z9-14 : OAc) was a major component of the sex pheromone of FAW females ${ }^{78}$ and the same has been identified from the moths collected from India. FAW pheromone has been recommended for monitoring and mass trapping. Efforts are being made to utilize the pheromone blends for mating disruption in FAW. The field efficacy of the lures ranges from 20 to 30 days and warrants frequent replacement, which adds to the cost of lure and labour for replacing them. The efficacy and dissipation of the release matrix is to be evaluated across the maize-growing tracts of India.

\section{Agro-ecological interventions for management}

Agro-ecological interventions are a core component of IPM integrating with breeding for pest resistance, biological control and safer pesticides. Cultural practices improve crop health, reduce pest population, and also provide shelter and alternative food sources to natural enemies of FAW, thus facilitating natural control ${ }^{79}$. Details of cultural and landscape management options are provided in the Supplementary Table 6 (refs 80-83).

In habitat management through 'push-pull' technology, pest-repelling legumes like Desmodium spp. or Tephrosia planted as intercrop 'push' the insect outside crop areas, while on the border pest-attractive trap plant species such as napier grass or Brachiaria spp. are planted to 'pull' the pest towards them. Intercropping with Tephrosia and Desmodium was found to reduce the number of FAW eggs laid on maize ${ }^{84}$. Identifying the location-specific intercropping/mixed cropping systems suited to varied agro-ecological regions for India could be the most sustainable technology, especially for smallholder farmers. Similarly, managing FAW by crop rotation, nutrient and water management needs standardization in the Indian conditions.

\section{Integrated pest management strategy for management}

An IPM package for FAW in maize was made by ICARIIMR in collaboration with ICAR-NBAIR and communicated to various stakeholders. Infestation threshold for the crop growth stages and spray schedule have been documented ${ }^{8}$.

\section{Intensity in India and possible impact on maize production}

The cumulative data published by the Department of Agriculture Cooperation and Farmers Welfare, GoI on 25 June 2019, indicate that Karnataka has the highest area affected with FAW (211,300 ha), followed by Telangana (24,288 ha), Maharashtra (5144 ha) and others ${ }^{8}$. FAW has 
been reported to cause economic damage in Tamil Nadu, Karnataka, Andhra Pradesh, Telangana and Maharashtra during rainy and post-rainy seasons of 2018 and 2019; Tripura during the last week of March 2019 and Mizoram in May 2019. With the behaviour of FAW, the pest may not establish or cause economic damage where the temperature drops below $10^{\circ} \mathrm{C}$ and rises beyond $40^{\circ} \mathrm{C}$. This may be the reason for the mild infestation of FAW in northern Rajasthan, Haryana and Punjab. FAW may not be a threat to the temperate northern hill zone as well, where the temperature drops well below $10^{\circ} \mathrm{C}$ during winter months. However, effective awareness campaigns coordinated with control measures could effectively contain the damage caused by the insect ${ }^{8}$. FAW is predicted to cause $21-53 \%$ loss in annual maize production in the absence of control measures ${ }^{85}$, while conservative estimates show yield reduction of $14.3-22.7 \%$ (ref. 86). However, rough estimates within India do not suggest damage of more than 5-10\% (based on field experience). Good rainfall and better management compensate the initial damage caused by the pest in majority of cases. However, if $5-10 \%$ loss in production is assumed in the affected maize areas, this amounts to reduction in total maize output by 37,000-75,000 tonnes in India. The estimate may increase or decrease depending on further spread or containment of FAW. This needs to be studied in detail in different agro-climatic zones of India.

\section{Conclusion}

FAW with its remarkable dispersal ability and preference for warmer temperature has spread from its tropical and subtropical habitat of the Americas. With the initial onslaught of FAW, GoI initiated timely strategies at policy level by establishing High Powered Committees both at Central and State levels in the FAW-affected states, extending label claims on insecticides against control of FAW. The research institutes, network projects and agricultural universities under the National Agricultural Research System, GoI, played a proactive role towards creation of awareness and management of FAW. India has taken a major role in managing FAW, which may be extended to other countries in the region under SouthSouth collaboration.

1. APEDA Agricultural and Processed Food Products Export Development Authority 2018-19, Ministry of Commerce and Industry, Government of India; https://apeda.gov.in.

2. Rakshit, S., Chikkappa, K. G., Jat, S. L., Dhillon, B. S. and Singh, N. N., Scaling-up of proven technology for maize improvement through participatory approach in India. In Best Practices of Maize Production Technologies in South Asia (eds Pandey, P. R. and Koirala, K. B.), 2017, SAARC Agriculture Centre, Dhaka, 2017, Page 36-60, p. 145; ISBN: 978-984-34-4172-02.

3. Rakshit, S. and Chikkappa, G. K., Perspective of maize scenario in India: way forward. Maize J., 2018, 7(2), 49-55.
4. Walton, W. R. and Luginbill, P., The fall army worm, or 'grass worm' and its control. Farmers Bull., 752, US Department of agriculture, 1916, p. 16.

5. Murua, G., Molina-Ochoa, J. and Coviella, C., Population dynamics of the fall armyworm, and its parasitoids in northwestern Argentina. Fla Entomol., 2006, 89(2), 175-182.

6. Goergen, G., Kumar, P. L., Sankung, S. B., Togola, A. and Tamo, M., First report of outbreaks of the fall armyworm a new alien invasive pest in West and Central Africa. PLOS ONE, 2016, 11(10), e0165632.

7. Sharanabasappa et al., First report of the fall armyworm, Spodoptera frugiperda (J. E. Smith) (Lepidoptera, Noctuidae), an alien invasive pest on Maize in India. Pest Manag. Hortl. Ecosyst., 2018, 24, 23-29.

8. Rakshit, S. et al., Fight against Fall armyworm Spodoptera frugiperda (J. E. Smith). ICAR-Indian Institute of Maize Research, Ludhiana, Punjab, 2019, p. 52.

9. Montezano, D. G. et al., Host plants of Spodoptera frugiperda in the Americas. Afr. Entomol., 2018, 26, 286-300.

10. Sparks, A. N., A review of the biology of the fall armyworm. Fla Entomol., 1979,1, 82-87.

11. ICAR-IIMR, Annual Report 2018-19, ICAR-Indian Institute of Millets Research, 2019, Rajendranagar, Hyderabad, p. 152.

12. Nagoshi, R. N. and Meagher, R. L., Using intron sequence comparisons in the triose-phosphate isomerase gene to study the divergence of the fall armyworm host strains. Insect Mol. Biol., 2016, 25(3), 324-337.

13. Swamy, H. M. M. et al., Prevalence of ' $\mathrm{R}$ ' strain and molecular diversity of fall armyworm in India. Indian J. Entomol., 2018, 80(3), 544-553.

14. Nagoshi, R. N., Dhanani, I., Asokan, R., Mahadevaswamy, H. M., Kalleshwaraswamy, C. M., Sharanabasappa and Meagher, R. L., Genetic characterization of fall armyworm infesting South Africa and India indicate recent introduction from a common source population. PLoS ONE, 2019, 14(5), e0217755.

15. Kakumani, Pavan Kumar, Pawan Malhotra, Sunil K., Mukherjee, Raj, K. and Bhatnagar, A draft genome assembly of the army worm, Spodoptera frugiperda. Genomics, 2014, 104(2), 134-143.

16. Gouin, A. et al., Two genomes of highly polyphagous lepidopteran pests (Spodoptera frugiperda) with different host-plant ranges. Sci. Rep., 2017, 7(1), 11816.

17. Liu, Huan, Tianming Lan, Dongming Fang, Furong Gui, Hongli Wang, Wei Guo and Xiaofang Cheng, Chromosome level draft genomes of the fall armyworm, an alien invasive pest in China. bioRxiv, 2019, 671560.

18. Wiseman, B. R., Painter, R. H. and Wasson, C. E., Detecting corn seedling differences in the greenhouse by visual classification of damage by the fall armyworm. J. Econ. Entomol., 1966, 59, 12111214.

19. Wiseman, B. R., Wassom, C. E. and Painter, R. H., Preference of first instar fall armyworm larvae for corn compared with Tripsacumdactyloides. J. Econ. Entomol., 1967, 60, 1738-1742.

20. Ni, X. et al., Foliar resistance to fall armyworm in corn germplasm lines that confer resistance to root and ear feeding insects. FlaEntomol., 2011, 94(4), 971-981.

21. Scott, G. E. and Davis, F. M., Registration of Mp 496 inbred of maize. Crop Sci., 1981, 21, 353.

22. Williams, W. P. and Davis, F. M., Registration of Mp 705, Mp 706 and Mp 707 germplasm lines of maize. Crop Sci., 1984, 24, 1217.

23. Scott, G. E. and Davis, F. M., Registration of Mp SWCB-4 population of maize. Crop Sci., 1981, 21, 148

24. Scott, G. E., Davis, F. M. and Williams, W. P., Registration of Mp 701 and Mp 702 germplasm lines of maize. Crop Sci., 1982, 22, 1270 .

25. Williams, W. P., Buckley, P. M., Hedin, P. A. and Davis, F. M., Laboratory bioassay for resistance in corn to fall armyworm 


\section{REVIEW ARTICLES}

and southwestern corn borer. J. Econ. Entomol., 1990, 83, 15781581

26. Viana and Guimaraes, P. E. O., Maize resistance to the lesser corn stalk borer and fall armyworm in Brazil. In Insect Resistant Maize: Recent Advances and Utilization; Proceedings of an International Symposium held at the International Maize and Wheat Improvement Center (CIMMYT) (ed. Mihm, J. A.), 27 November-3 December 1994, Mexico, D.F., CIMMYT, 1997.

27. Welcker, C. J. D., Gilet, D. Clavel and Guine, I., Response to selection for resistance to leaf feeding by fall armyworm in PopG, a guadeloupe maize population. In Insect Resistant Maize: Recent Advances and Utilization; Proceedings of an International Symposium held at the International Maize and Wheat Improvement Center (CIMMYT) (ed. Mihm, J. A.), 27 November-3 December 1994, Mexico, D.F., CIMMYT, 1997.

28. Wiseman, B. R., Davis, F. M., Williams, W. P. and Widstrom, N W., Resistance of a maize population, GT-FAWCC (C5), to fall armyworm larvae. Fla. Entomol., 1996, 79, 329-336.

29. Abel, C. A., Wilson, R. W., Wiseman, B. R., White, W. H. and Davis, F. M. Conventional resistance of experimental lines to corn ear worm, fall armyworm, South Western corn borer and sugarcane borer. J. Econ. Entomol., 2000, 93(3), 982-988.

30. Ni, X., Kedong Da, Buntin, G. D. and Brown, S. L., Physiological basis of fall armyworm resistance in seedlings of maize inbred lines with varying levels of silk maysin. Fla. Entomol., 2008, 91(4), 537-545.

31. Ni, X., Xu, W., Blanco, M. H. and Williams, W. P., Evaluation of fall armyworm resistance in maize germplasm lines using visual leaf injury rating and predator survey. Insect Sci., 2014, 21(5), 541-555.

32. Prasanna, B. M., Host Plant Resistance to Fall Armyworm: Status and Prospects. WTO meeting, 19 March 2019.

33. Diawara, M. M., Hill, N. S., Wiseman, B. R. and Isenhour, D. J., Panicle-stage resistance to Spodoptera frugiperda in converted sorghum assessions. J. Econ. Entomol., 1991, 84, 337-344.

34. Diawara, M. M., Wiseman, B. R., Isenhour, D. J. and Hill, N. S., Sorghum resistance to whorl feeding by larvae of the fall armyworm (Lepidoptera: Noctuidae) J. Agric. Entomol., 1992, 9(1), 41-53

35. Harris-Shultz, K. R., Xinzhi, Ni, William, F. Anderson and Joseph E. Knoll, Evaluation of whorl damage by fall armyworm on field and greenhouse-grown sweet sorghum plants. J. Entomol. Sci., 2015, 50(1), 14-27.

36. Leuck, B. D., The role of resistance in pearl millet in control of the fall armyworm. J. Econ. Entomol., 1970, 63, 1679-1681.

37. Bernal, J. S., Melancon, J. E. and Zhu-Salzman, K., Clear advantages for fall armyworm larvae from feeding on maize relative to its ancestor Balsas teosinte may not be reflected in their mother's host choice. Entomol. Exp. Appl., 2015, 155, 206-217.

38. Moya-Raygoza, G., Early development of leaf trichomes is associated with decreased damage in teosinte, compared with maize, by Spodoptera frugiperda. Annl. Entomol. Soc. Am., 2016, 109, 737743.

39. Davis, F. M., Baker, G. T. and Williams, W. P., Anatomical characteristics of maize resistant to leaf feeding by southwestern corn borer (Lepidoptera: Pyralidae) and fall armyworm. J. Agric. Entomol., 1995, 12(1), 55-65.

40. Hedin, P. A., Williams, W. P., Davis, F. M. and Buckley, P. M., Roles of amino acids, protein, and fiber in leaf-feeding resistance of corn to the fall armyworm. J. Chem. Ecol., 1990, 16(6), 1977-1995.

41. Yang, G., Wiseman, B. R., Isenhour, D. J. and Espelie, K. E., Chemical and ultra structural analysis of corn cuticular lipids and their effect on feeding by fall armyworm larvae. J. Chem. Ecol., 1993, 19(9), 2055-2074.

42. Snook, M. E., Wiseman, B. R., Widstrom, N. W. and Wilson, R. L., Chemicals associated with maize resistance to corn earworm and fall armyworm. In Insect Resistant Maize: Recent Advances and Utilization; Proceedings of an International Symposium held at the International Maize and Wheat Improvement Center (CIMMYT) (ed. Mihm, J. A.), 27 November-3 December 1994, Mexico, D.F. CIMMYT, 1997.

43. Qi, J. et al., Current understanding of maize and rice defense against insect herbivores. Plant Divers., 2018, 40(4), 189-195.

44. Chen, Y., Ni, X. and Buntin, G. D., Physiological, nutritional and biochemical bases of corn resistance to foliage-feeding fall armyworm. J. Chem. Ecol., 2009, 35(3), 297-306.

45. Shivaji, R. et al., Plants on constant alert: elevated levels of jasmonic acid and jasmonate-induced transcripts in caterpillarresistant maize. J. Chem. Ecol., 2010, 36(2), 179-191.

46. Smith, W. E. et al., A maize line resistant to herbivory constitutively releases (E)-beta-caryophyllene. J. Econ. Entomol., 2012, 105(1), 120-128.

47. Brooks, T. D., Willcox, M. C., Williams, W. P. and Buckley, P. M., Quantitative trait loci conferring resistance to fall armyworm and southwestern corn borer leaf feeding damage. Crop Sci., 2005, 45(6), 2430-2434.

48. Brooks, T. D., Shaun Bushman, B., Williams, W. P., McMullen, M. D. and Buckley, P. M., Genetic basis of resistance to fall armyworm and southwestern corn borer leaf-feeding damage in maize. J. Econ. Entomol., 2007, 100(4), 1470-1475.

49. Womack, E. D., Warburton, M. L. and Williams, W. P., Mapping of quantitative trait loci for resistance to fall armyworm and southwestern corn borer leaf-feeding damage in maize. Crop Sci., 2018, 58(2), 529-539.

50. Hardke, J. T., Leonard, B. R., Huang, F. and Jackson, R. E., Damage and survivorship of fall armyworm on transgenic field corn expressing Bacillus thuringiensis Cry proteins. Crop Protec., 2011, 30(2), 168-172.

51. Storer, N. P. et al., Discovery and characterization of field resistance to Bt maize: Spodoptera frugiperda in Puerto Rico. J. Econ. Entomol., 2010, 103, 1031-1038; doi:10.1603/EC10040.

52. Huang, F. et al., Cry1F resistance in fall armyworm single gene versus pyramided Bt maize. PLoS ONE, 2014, 9, Article e1:12958.

53. Omoto, C. et al., Field-evolved resistance to $C r y 1 A b$ maize by Spodoptera frugiperda in Brazil. Pest Manag. Sci., 2016, 72(9), 1727-1736.

54. Chandrasena, D. I., Signorini, A. M., Abratti, G., Storer, N. P., Olaciregui, M. L., Alves, A. P. and Pilcher, C. D., Characterization of field-evolved resistance to Bacillus thuringiensis-derived Cry1F $\delta$-endotoxin in Spodoptera frugiperda populations from Argentina. Pest Manage. Sci., 2018, 74, 746-754; doi:10.1002/ ps.4776.

55. Prasanna, B. M. et al. (eds), Host plant resistance to fall armyworm. In Fall Armyworm in Africa: A Guide for Integrated Pest Management, Mexico, CDMX: CIMMYT, 2018, 1st edn, Chap. 4, pp. 45-62.

56. Sisay, B., Tefera, T., Wakgari, M., Ayalew, G. and Mendesil, E., The efficacy of selected synthetic insecticides and botanicals against fall armyworm in maize. Insects, 2019, 1, 10.

57. Garcia, C., González, M. B. and Bautista, N., Pathogenicity of isolates of entomopathogenic fungi against Spodoptera frugiperda and Epilachnavarivestis. Rev. Colomb. Entomol., 2011, 37, $217-$ 222.

58. Komivi, S. A., Kimemia, J. W., Ekesi, S., Khamis, F. M., Ombura, O. L. and Subramanian, S., Ovicidal effects of entomopathogenic fungal isolates on the invasive fall armyworm. J. Appl. Entomol., 2019, 143, 626-634.

59. Cruz-Avalos, A. M., Bivian-Hernndez MdeL, Ibarra, J. E. and Rincón-Castro MaCD., High virulence of Mexican entomopathogenic fungi against fall armyworm. J. Econ. Entomol., 2019, 112, 99-107.

60. Polanczyk, R. A., Silva, R. F. P. D. and Fiuza, L. M., Effectiveness of Bacillus thuringiensis strains against Spodoptera frugiperda. Braz. J. Microbiol., 2000, 31, 164-166. 
61. Garcia, L. C., Carlos, G., Raetano, C. G. and Leite, E. L. G., Application technology for the entomopathogenic nematodes Heterorhabditisindica and Steinernema sp. (Rhabditida: Heterorhabditidae and Steinernematidae) to control Spodoptera frugiperda in corn. Neotrop. Entomol., 2008, 37, 305-311.

62. Gomez, J., Guevara, J., Cuartas, P., Espinel, C. and Villamizar, L., Microencapsulated Spodoptera frugiperda nucleopolyhedrovirus: insecticidal activity and effect on arthropod populations in maize. Biocontrol. Sci. Technol., 2013, 23, 829-846.

63. Haase, S., Sciocco-Cap, A. and Romanowski, V., Baculovirus insecticides in Latin America: historical overview, current status and future perspectives. Viruses, 2015, 7, 2230-2267.

64. Mallapur, C. P., Anjan Kumar Naik, Sireesh Hagari, Praveen, T., Patil, R. K. and Lingappa, S., Potentiality of Nomuraea rileyi (Farlow) Samson against the fall armyworm infesting maize. J. Entomol. Zool. Stud., 2018, 6, 1062-1067.

65. Sharanabasappa, Kalleshwaraswamy, C. M., Poorani, J., Maruthi, M. S., Pavithra, H. B. and Diraviam, J., Natural enemies of Spodoptera frugiperda (J. E. Smith) (Lepidoptera: Noctuidae), a Recent Invasive Pest on Maize in South India. Fla. Entomol., 2019, 102, 619-623.

66. Shylesha, A. N. et al., Studies on new invasive pest Spodopter afrugiperda (J. E. Smith) (Lepidoptera: Noctuidae) and its natural enemies. J. Biol. Control., 2018, 32(3), 1-8.

67. Beserra, E. B., Carlos, T., Dias, D. S. and Parra, J. R. P., Distribution and natural parasitism of Spodoptera frugiperda eggs at different phenological stages of corn. Fla. Entomol., 2002, 85, 588-593.

68. Sisay, B. et al., Fall armyworm infestations in East Africa: assessment of damage and parasitism. Insects, 2019, 10, 195.

69. Wheeler, G. S., Ashley, T. R. and Andrews, K. L., Larval parasitoids and pathogens of the fall armyworm in Honduran maize. Entomophaga, 1989, 34, 331.

70. Robert, L. et al., Parasitoids attacking fall armyworm in sweet corn habitats. Biol. Control., 2016, 95, 66-72.

71. ICAR-NBAIR Annual Report 2018-19. ICAR-National Bureau of Agricultural Insect Resources, Bengaluru, India, 2019, vi + pp. 122.

72. De Brito, C. H., Mezzomo, J. A., Batista, J. L., Barbosa, M. and Murata, E. A., Bioatividade de extratosvegetaisaquosossobre Spodoptera frugiperda emcondições de laboratorio. Manejo Integrado de Plagas y Agroecología (Costa Rica) 2004, 71, 41-45.

73. Rossi, G. D., Santos, C. D., Carvalho, G. A., Alves, D. S., Pereira, L. L. S. and Carvalho, G. A., Biochemical analysis a castor bean leaf extract and its insecticidal effects against Spodoptera frugiperda. Neotrop. Entomol., 2012, 41, 503-509.

74. Knaak, N., Tagliari, M. S., Machado, V. and Fiuza, L. M. Atividadeinseticida de extratos de Plantas Medicinaissobre Spodoptera frugiperda (J. E. Smith). BioAssay, 2012, 7, 1-6.
75. Silva, M. S., Broglio, S. M. F., Trindade, R. C. P., Ferrreira, E. S., Gomes, I. B. and Micheletti, L. B., Toxicity and application of neem in fall armyworm. Com. Sci., 2015, 6, 359-364.

76. Martinez, A. M., Aguado-Pedraza, A. J., Vinuela, E., RodríguezEnriquez, C. L., Lobit, P., Omez, B. and Ineda, S., Effects of ethanolic extracts of Argemoneo chroleuca (Papaveraceae) on the food consumption and development of Spodoptera frugiperda. Fla. Entomol., 2017, 100, 339-345.

77. Mora, J. and Blanco-Metzler, H., Evaluation of botanical insecticides in controlling the population of fall armyworms present on corn crops (Zea mays) located in Santa Cruz, Guanacaste. IOP Conf. Ser.: Earth Environ. Sci., 2018, 215, 012-013.

78. Sekul, A. A. and Sparks, A. N., Sex pheromone of the fall armyworm moth: isolation, identification and synthesis. J. Econ. Entomol., 1967, 60, 1270-1272.

79. Thierfelder, C. L., Rusinamhodzi, A. R., Ngwira, W., Mupangwa, I., Nyagumbo, G. T., Kassie and Cairns, J. E., Conservation agriculture in southern Africa: advances in knowledge. Renew. Agric. Food Syst., 2015, 30, 328-348.

80. Vanden Berg, J. and Van Rensburg, J. B. J., Infestation and injury levels of stem borers in relation to yield potential of grain sorghum. S Afr. J. Plant Soil, 1991, 8, 127-131.

81. Altieri, M. A. and Nicholls, C. I., Soil fertility management and insect pests: harmonizing soil and plant health in agroecosystems. Soil. Till. Res., 2003, 72, 203-211.

82. Pichersky, E. and Gershenzon, J., The formation and function of plant volatiles: perfumes for pollinator attraction and defense. Curr. Opin. Plant Biol., 2002, 5(3), 237-243.

83. Altieri, M. A., Funes-Monzote, F. R. and Petersen, P., Agroecologically efficient agricultural systems for smallholder farmers: contributions to food sovereignty. Agron. Sustain. Dev., 2012, 32, $1-13$.

84. Harrison, R. D., Thierfelder, C., Baudron, F., Chinwada, P., Midega, C., Schaffner, U. and Van den Berg, J., Agro-ecological options for fall armyworm management: Providing low-cost, smallholder friendly solutions to an invasive pest. J. Environ. Manage., 2019, 243, 318-330.

85. Day, R. et al., Fall armyworm: impacts and implications for Africa. Outlooks on Pest Manag., 2017, 28(5), 196-201.

86. Harrison, F. P., Observations on the infestation of corn by fall armyworm (Lepidoptera: Noctuidae) with reference to plant maturity. Florida Entomol., 1984, 67, 333-335.

Received 25 January 2020; revised 18 March 2020

doi: $10.18520 / \mathrm{cs} / \mathrm{v} 119 / \mathrm{i} 1 / 44-51$ 